\title{
Linking well-being with cultural revitalization for greater cognitive justice in conservation: lessons from Venezuela in Canaima National Park
}

\author{
Iokiñe Rodriguez $^{1}$
}

\begin{abstract}
Across the globe, conservation policies have often suppressed nonscientific forms of knowledge and ways of knowing nature, along with the social practices of the groups that are informed by such knowledge. Reversing this process of epistemic supremacy is crucial both for achieving greater cognitive justice in conservation areas and ensuring that conservation aims are achieved. Doing so, however, is not an easy task. In situations of cultural violence, hidden environmental knowledge is not easily made visible unless adequate conditions for it to emerge are created. I show that one way forward is by conservation engaging with the well-being agendas of indigenous people, in particular, with the construction of their life plans. This discussion is illustrated through a case study in Canaima National Park, Venezuela, where over the last 20 years, social-ecological research has been studying existing conflicts over the use of fire while supporting the development of Pemon (the indigenous peoples in this area) Life Plans. Assisting in the development of life plans through participatory historical reconstructions, territorial self-demarcation processes, and facilitation of community reflexivity about its social-ecological changes and desired future has been decisive for the Pemon, and has revealed fire management knowledge that challenges conventional explanations of landscape change that simplistically place the blame for such changes on the local use of fire. This local knowledge, combined with results from studies of Pemon fire regimes, fire behavior ecology, and paleoecological research, now informs a counter narrative of landscape change that is influencing a shift in environmental discourse and policy-making toward an intercultural fire management approach. By documenting how social-ecological research has engaged with the Pemon Life Plan processes, I show the important role that cultural revitalization plays in making hidden and silenced local environmental knowledge more visible, and hence, in achieving greater cognitive justice in conservation.
\end{abstract}

Key Words: cognitive justice; cultural revitalization; dialogues of knowledge; fire; well-being

\section{INTRODUCTION}

Conservation policies across the globe have often suppressed nonscientific forms of knowledge and ways of knowing nature, along with the social practices of groups that are informed by such knowledge (Santos 2007, Berkes 2008, Ojha et al. 2009, Escobar 2010, Martin 2017). Apart from the impact that this has had on local peoples' livelihoods and identities, the exclusion of local knowledge from conservation practice has often resulted in inadequate environmental policies (Leach and Mears 1996). Reversing this process of epistemic supremacy is crucial both for achieving greater cognitive justice in conservation areas and for ensuring that conservation aims are achieved. Doing so, however, is not an easy task. In situations of prolonged cultural violence (Galtung 1990), hidden environmental knowledge is not easily made visible unless adequate conditions for it to emerge are created.

I argue that one way forward is by conservation engaging with the well-being agendas of indigenous people, and in particular, the construction of their life plans. A "life plan" is a plan made by indigenous people in an effort to maintain traditions, customs, and the hope of having a society with its own identity based on the traditional knowledge of its people (Jansasoy and Pérez 2005). Apart from contributing to a process of cultural revitalization, the development of life plans offers a unique opportunity to create dialogues of knowledge between social-ecological scientists and indigenous peoples over contentious environmental issues, which can in turn lead to greater cognitive justice.

I illustrate this discussion with a case study in Canaima National Park, Venezuela, where over the last 20 years, social-ecological research has been studying existing conflicts over the use of fire, while supporting the development of Pemon (the indigenous peoples in this area) Life Plans. Assisting in the development of life plans through participatory historical reconstructions, territorial self-demarcation processes, and facilitation of community reflexivity about its social-ecological changes and desired future has been decisive for the Pemon, and has revealed fire management knowledge that challenges conventional explanations of landscape change that have simplistically placed the blame for such changes on the local use of fire. As a result, a new intercultural fire management narrative has started to emerge in the park.

By documenting how social-ecological research has engaged with the Pemon Life Plan processes, I seek to show the important role that cultural revitalization plays in making hidden and silenced local environmental knowledge more visible, and hence, in achieving greater cognitive justice in conservation. I draw on personal observations, conversations, results from collaborative work, and secondary data I have collected during my participation or engagement with three separate but interlinked socialecological research projects over the last 20 years. It is not the objective of this paper to present the methods or results of the fire research as such because this work has already been published elsewhere (Rodriguez 2007, Sletto 2008, 2009, Bilbao et al. 2010, Rodriguez et al. 2013, Sletto and Rodriguez 2013).

The paper is structured in five parts. In the first section, I provide a discussion of the main concepts that guide this paper: cognitive justice, cultural revitalization, and well-being. In the second section, I present an overview of Canaima National Park, with a focus on its history of epistemic violence, illustrated through the protracted conflict over the use of fire. The third section explains 
the methods that the three social-ecological research projects have used to develop dialogues about fire by linking with Pemon Life Plans. In the fourth section, I present a discussion of the contributions that this way of doing research has had in creating greater cognitive justice in the park, which is followed by a section in which I highlight some of the challenges of this way of doing research. Finally, I close with the main conclusions this case study offers to think about cognitive justice, cultural revitalization, and local conceptualization of well-being as a supportive base for conservation practices.

\section{COGNITIVE JUSTICE, CULTURAL REVITALIZATION, AND WELL-BEING FOR CONSERVATION}

Social injustices caused to local communities and indigenous peoples by conservation policies have been extensively documented for more than two decades (Ghimire and Pimbert 1997, Brechin et al. 2003, Martin 2017). Many of these injustices arise out of the exclusion and marginalization of local worldviews, values, and knowledge from conservation policy-making and management. As a result, increasing attention is currently being paid to developing environmental governance systems that incorporate different perspectives of nature and forms of environmental knowledge. Environmental scholars and policymakers now explore processes of coproduction of knowledge (ICSU 2005, Berkes 2008), knowledge articulation (Galopin and Vessuri 2006), knowledge integration (Raymond et al. 2010), knowledge systems (Cash et al. 2003), and transdisciplinarity (Pregernig 2006), among others.

Yet, in many parts of the world, the exclusion of alternative knowledges of nature in conservation has continued, sometimes even as part of more plural modes of environmental governance. For instance, Ojha et al. (2009) show how in Nepal, despite the implementation of several participatory approaches for forest management, processes of symbolic violence have continued through claims of superior knowledge used by some actors to legitimate closure in deliberation on forest governance practices. On a different note, in Latin America, Pérez and Argueta (2011) documented how new participatory approaches put in practice in conservation and environmental management have ended up extracting or decontextualizing local knowledge, thereby offering little opportunity for a dialogue between knowledge systems. Despite the efforts at democratizing knowledge, epistemic domination continues in many parts of the world due to the strong hold that a Western scientific worldview continues to have in knowledge hierarchies in conservation (Martin 2017).

In 1997, Visvanathan (1997) proposed the term "cognitive justice" to legitimize the right of different knowledge systems to exist, but most importantly to suggest a way out of this situation of epistemic supremacy. Cognitive justice, he said, "demands recognition of knowledges, not only as methods but as ways of life. This presupposes that knowledge is embedded in an ecology of knowledges, where each knowledge has its place, its claim to a cosmology, its sense as a form of life. In this sense knowledge is not something to be abstracted from a culture as a life form; it is connected to a livelihood, a life cycle, a lifestyle; it determines life chances." According to this perspective, a greater recognition of alternative knowledges in conservation requires changing the conditions of dialogue between knowledge systems to a situation in which traditionally excluded actors, such as indigenous peoples, do not have to fit into the structures and standards of Western knowledge.

Seen in this way, cognitive justice has to be part of a wider process of decolonization of knowledge that must start at the universities and critically question "the how" and "what for" of knowledge production (Santos 2007, Mignolo 2008) in order to generate new proposals for collaboration with those conventionally considered "study subjects" (Perry and Rappaport 2013) or "conservation beneficiaries." This implies going beyond generating methodologies for communities and indigenous peoples to be partners as researchers or resource managers in conservation to being willing to respond through research and conservation interventions to the social, cultural, political, economic, and environmental imperatives of local and indigenous peoples' agendas (Smith 2012).

As Walsh (2005) suggests, this entails creating new knowledge in a way that it confronts existing relations of domination in hegemonic paradigms, and helps strengthen what the people themselves understand and reconstruct as "theirs," in relation to identities, differences, and knowledge. This emphasis on reconstructing, recovering, and revaluing local knowledge is key to achieving cognitive justice in conservation. Local knowledge has been made invisible not only by dominant values and institutional arrangements in conservation that determine what is and is not valid knowledge, but also through structural forces linked to modernization that have had a role in erasing local identities and worldviews (Pretty et al. 2009).

Indeed, many local and indigenous communities are increasingly experiencing a disconnection from nature and the local environment because of rapid processes of cultural change and assimilation policies (Pilgrim and Pretty 2013). This gives rise to intracommunity and intergenerational tensions and conflicts over the use of the environment, which potentially shut down or severely limit the possibility of a symmetrical dialogue between different knowledge systems. Thus, in order to do cognitive justice in conservation areas, in many parts of the world, endogenous processes of cultural revitalization are needed to strengthen indigenous peoples' own knowledge systems and cultural identities.

In some parts of the world, local revitalization projects are well underway in areas such as traditional foods, economies, education, language, cultural practices, and rights (Pilgrim and Pretty 2013). Nonetheless, great work still needs to be done to ensure that cultural revitalization is not seen as a secondary objective or a stepping-stone to protecting biological diversity (Pretty et al. 2009). I argue that a way of avoiding this is by feeding into indigenous peoples' own cultural revitalization agendas, which in the case of Latin America largely follows two principal trajectories: the pursuit of territorial rights, and the development of their own life plans (Planes de Vida). While territorial control is the material base for cultural survival, the life plan is the spiritual and philosophical base (García 2009).

The concept of a life plan was originally conceived in Colombia (Jansasoy and Pérez 2005), where life plans are used as articulating mechanisms between indigenous peoples and external advisers in land use planning processes (Pérez and Argueta 2011). 
In the late 1990s, the Pemon indigenous people from Canaima National Park started using life plans as a tool for cultural revitalization and the definition of their own well-being agenda. Similar to many indigenous peoples in the region, they were concerned about the accelerated process of cultural change they were experiencing and about the ubiquity of imposed development and conservation policies in their lands. Since then, they have made important progress in positioning the life plan concept and process in the area (Gomez 2004, Pizarro 2006, World Bank 2006). Most significantly, social-ecological researchers started engaging with the Pemon Life Plan as a platform from which to do joint research on issues related to social-ecological change and fire use in the national park. As I will demonstrate, this change in terms of the conversation about the environment significantly changed the power relations in knowledge production and helped advance a process of cognitive justice in Canaima National Park.

\section{CANAIMA NATIONAL PARK: A LAND OF CONFLICTS AND EPISTEMIC VIOLENCE}

Canaima National Park is located in southeastern Venezuela, near the border with Brazil and Guyana (Fig. 1). It protects the northwestern portion of the Guyana Shield, an ancient geological formation shared with Brazil, the Guyanas, and Colombia. The park was created in 1962 with an initial area of $10,000 \mathrm{~km}^{2}$ and was extended to $30,000 \mathrm{~km}^{2}$ in 1975 to protect its watershed. The Guri Dam, which generates $70 \%$ of Venezuela's electricity, is located $300 \mathrm{~km}$ downstream of the northwestern border of the Canaima National Park. The best-known landscape components of Canaima National Park are the "tepuyes," ancient mountains in the form of a plateau, which receive their name from the Pemon word tüpü. Canaima National Park's vegetation is markedly divided between a forest-savanna mosaic in the eastern sector, known as the Gran Sabana, and an evergreen forest in the western zone. In recognition of its extraordinary landscapes and geological and biological values, the park was registered on the list of UNESCO Natural World Heritage Sites in 1994.

Fig. 1. Location of Canaima National Park (highlighted in the black and white shaded area).

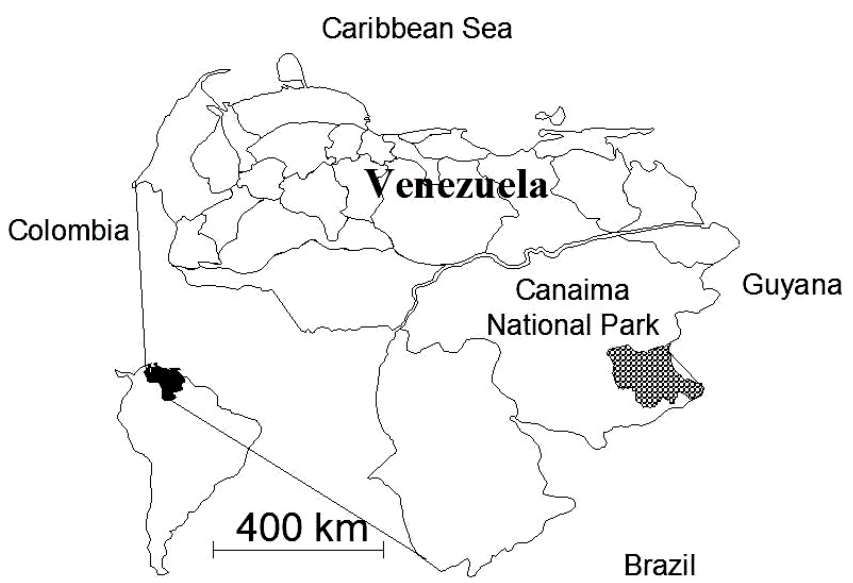

Brazil
A wide variety of interests led to tension in Canaima National Park, largely because the protected area was established, without any prior consultation, on a territory occupied ancestrally by the Pemon people - the main occupants of this vast area. With an estimated population of 20,000 people, most of the Canaima National Park Pemon live in settlements of 100-1000 inhabitants, although some still maintain the traditional system of scattered, nuclear family settlements. Their lifestyle is based largely on traditional activities: agriculture, fishing, hunting, and gathering, although there is increasing work in tourism and associated activities (e.g., handicrafts), as well as public administration posts (e.g., teachers, nurses, community police, and municipal staff), and more recently, mining (Rodriguez 2014). Although the 1999 National Constitution recognizes territorial property rights for indigenous peoples, to date, the Pemon do not have territorial ownership.

Despite the strong cultural bonds that the Pemon have with their land, their relationship with the Canaima National Park has not been a happy one. The very name of the park symbolizes a long history of antagonism between the Pemon people and the environmental managers of this area. To the detriment of the park management, "Canaima" in Pemon means "spirit of evil" and "refers to [a person who perpetrates] sorcery, using secret methods that we call witchcraft" (Butt-Colson 1985)[1]. The lack of sensitivity in naming the park is one of the many ways in which the Pemon have been made strangers in their own land. This is due to a style of environmental management and development planning that has systematically excluded their cultural values, knowledge, and notions of authority and territorial property.

The result has been a high level of conflict over a variety of issues, such as tourism management, land use practices, state promoted large-scale development projects, and more recently, mining. These various conflicts have been unfolding in a context of rapid cultural change that has resulted from educational and national integration policies that have been implemented since 1940. As a result, the Pemon have increasingly been experiencing a feeling of disorientation about who they want to be in the future and how they wish to live as a people. In particular, there is great concern over the loss of self-esteem of younger generations, as well as the loss of Pemon knowledge and traditions. Furthermore, these processes of cultural change have led to increasing tensions between young Pemon and elders over current ways of life. This combination of factors puts the Pemon in a vulnerable situation when they engage in dialogue with other stakeholders about development and territorial management. The greatest threat is the imposition of other peoples' well-being agendas over theirs.

In terms of the Canaima National Park's conservation objectives, one of the most contentious issues has been the extensive use of fire by the Pemon in conucos (slash and burn) agriculture and in savanna burning; both indigenous practices are considered by environmental managers as a threat to the watershed conservation functions of Canaima National Park. Despite a variety of strategies developed by the government to change or eliminate the use of fire in agriculture and the savannas, many Pemon, especially the elders and those living in more isolated communities, have continued using fire extensively. By contrast, younger Pemon generations have become gradually more critical of the use of fire, and as a result, intergenerational tensions on this topic have become increasingly common. 
The dominant view of fire in Canaima National Park is a product of more than a century of misinterpretation of the Pemon's use of fire by nonindigenous people (e.g., Schomburgk 1840, Boddam-Whetham 1879, Im Thurn 1885[1934], Appun 1893, Clementi 1920, Tate 1930). Since colonial contact, fire has been highlighted as a cause of the systematic reduction in the forests of the Gran Sabana and conversion to grassland (Tate 1930, Christoffel 1939). Underlying the way traditional burning practices have been seen throughout the 19th and 20th centuries is the perception that the Pemon lack the necessary knowledge to use fire or manage the land due to their alleged recent arrival to the area (300 years). Such a perception, together with the strategic importance of the Gran Sabana for hydroelectric power, was used by the State in 1981 to justify external intervention to manage fire in the Canaima National Park through a fire control program managed by the Electricity Company of Caroni (formerly EDELCA, now CORPOELEC). The fire control program has three components: (a) firefighting, (b) fire prevention through environmental education, and (c) research on fire (Gómez 1995). Pemon involvement has been restricted to direct employment as manual laborers (firefighters) and as subjects in environmental education activities. While efforts have been made to involve young Pemon in some aspects of the fire control program, Pemon elders have been systematically excluded.

Until recently, research on fire ecology had paid scant attention to the study of local fire regimes and to understanding the ecological knowledge that underpins it. This contributed to the perpetuation of a monolithic view of fire among managers in the park, and created a strong clash between two different knowledge systems about fire. This situation started to change when researchers began linking with a Pemon well-being agenda.

\section{LINKING SOCIAL-ECOLOGICAL RESEARCH WITH INDIGENOUS LIFE PLANS}

“...our own Life Plan will not only strengthen us as a people, but also facilitate the necessary interactions with the institutions with which the Pemon relate" (Juvencio Gomez, Chief General, cited in World Bank 2006).

The person who championed the idea life plans in Canaima National Park is Juvencio Gomez, former Pemon chief from the village of Kumararakapay. In the late 1990s, he participated in a number of international indigenous rights forums and heard that indigenous peoples in Colombia were conceptualizing development (or well-being) in their own terms through the construction of life plans (Planes de Vida). He learned that:

A Plan de Vida is a plan made by indigenous
organizations and communities in an effort to survive and
to maintain traditions, customs, and the hope of having
a society with its own identity based on the traditional
knowledge of its people. It is a means of guaranteeing
better conditions and a better quality of life for
indigenous communities. However, it is also a document
to be used in negotiations with both the regional and
national government. It includes the issues of health,
education, territory, the environment, natural resources,
the economy and production, government, justice, youth,
and women's and gender issues, among others (Perez 2009).

Thus, the Colombian experience became an inspiration and a path to follow in the search for a self-defined society and future. Yet, although the idea of having a document to present in negotiations with national and regional authorities was appealing, what mostly sparked Juvencio Gomez's interests was the possibility of developing a space for self-reflection about "who the Pemon are and want to be as a People." It was his view that the starting point for conceptualizing their local pathway to well-being was to confront their identity by reconnecting with their past and analyzing their current situation. Other Pemon leaders have shared this view of the life plans as a space for self-critical analysis about their current situation and desired future:

"Perhaps the Life Plan can become our space to think and reflect about ourselves. Just as Western people have universities, we also need a space to think and mature our ideas as a society" (Valeriano Constati, Kavanayen, 2008, personal communication).

Although documents defining a Pemon Life Plan have been produced (Gomez 2004, Pizarro 2006, World Bank 2006), to a large extent, rather than a means to an end, the Pemon Life Plan process has been conceptualized as an end in itself: as a space for self-critical reflection about different aspects of their culture. It is this aspect of the Life Plan that social-ecological research has been contributing to in the last two decades through facilitating community reflexivity about social-ecological changes and desired futures and helping revitalize culture in different aspects of community life.

I describe here the methods used in three different but complementary research processes developed over the last 20 years to link with the Pemon Life Plan, while also helping to advance an understating of landscape change and the social and ecological dimensions of the use of fire in the Canaima National Park (see Table 1 for a summary). It is important to point out that in all three cases, linking with the Pemon Life Plans was a condition put forth by the Pemon themselves to allow research to be carried out in their lands. The specific way in which support for the Life Plan processes was agreed upon in each case depended on what the researchers could offer within the limits of their own research projects and objectives. In all cases, the terms of collaboration were agreed upon with the village chiefs and council of elders, and then were presented at community assemblies for their discussion and approval. Beyond contributing to a Pemon agenda, this way of doing research opened up opportunities for truthful dialogue and discussions over very contentious and silenced issues related to landscape use and change that would not have taken place in a less engaged form of research.

\section{Researching social-environmental conflicts}

The first experience took place in 1999 in Kumarakapay, the largest Pemon community in Sector 5 (one of eight self-designated sectors of the Pemon territory), as part of my $\mathrm{PhD}$ field research. I was interested in studying social-environmental conflicts in the park, one of them being the conflict over the use of fire. As a condition for being allowed to do my research, Juvencio Gomez, at that time chief of Kumarakapay, asked me to assist him in starting to develop the community's Life Plan. The result was a year-long participatory process of self-reflection about the past, present, and desired future of the Pemon from Kumarakapay. The process was facilitated by the chief, his wife, and myself, and was carried out in conjunction with a group of approximately 30 people (about half elders and half youth) who were supportive of the chief's concern for cultural revitalization and the idea of developing a community life plan. 
Table 1. Summary of methods used by social-ecological research in support of the Pemon Life Plans.

\begin{tabular}{|c|c|c|}
\hline 1999 & $2000-2004$ & $2007-2014$ \\
\hline $\begin{array}{l}\text { Cultural revitalization activities } \\
\text { Kumarakapay: } \\
\text { Participatory analysis of the past, present, and } \\
\text { future } \\
\text { 1) Community reflexive workshops: } \\
\text { - community history (3) } \\
\text { - current situation (2) } \\
\text { - desired future (1) }\end{array}$ & $\begin{array}{l}\text { Kumarakapay and Sector 5: } \\
\text { Participatory mapping } \\
\text { 1) Training in ethno-cartography ( } 30 \text { people) } \\
\text { 2) Geo-referencing of landscape uses and sites } \\
\text { of cultural value in } 12 \text { communities of Sector } 5 \\
\text { 3) Community workshops to document } \\
\text { traditional geographic knowledge (4) }\end{array}$ & $\begin{array}{l}\text { Kumarakapay: } \\
\text { 1) Community reflexive workshops: } \\
\text { - historical reconstruction (6) } \\
\text { 2) Community meetings to agree to copyrights } \\
\text { of publication of history book (1) } \\
\text { 3) Joint writing and edition sessions for history } \\
\text { book (4) } \\
\text { Kavanayen: } \\
\text { Participatory analysis of the past, present, and } \\
\text { future } \\
\text { 1) Community reflexive workshops: } \\
\text { - analysis of social-ecological change and future } \\
\text { scenarios (1) } \\
\text { - community history (1) } \\
\text { - our Life Plan: where do we come from and } \\
\text { where are we going? (1) } \\
\text { Participatory historical reconstruction project } \\
\text { 1) Oral testimonies from elders (40) } \\
\text { 2) Meetings with council of elders (6) } \\
\text { 3) History video (1) } \\
\text { 4) Community workshops with young Pemon } \\
\text { and elders on the meanings of the landscape (2) } \\
\text { 5) Community mapping of sites of historical } \\
\text { value }\end{array}$ \\
\hline $\begin{array}{l}\text { Fire-related activities } \\
\text { Kumarakapay: } \\
\text { Participatory analysis of Pemon perspectives on } \\
\text { fire management } \\
\text { 1) In-depth interviews on fire (29) } \\
\text { 2) Community meeting to discuss result of } \\
\text { interviews (1) }\end{array}$ & $\begin{array}{l}\text { Kumarakay and Montebello } \\
\text { Participatory analysis of changes in the use fire } \\
\text { 1) Fire interviews of young Pemon ( } 36 \text { and } 10 \text {, } \\
\text { respectively) } \\
\text { 2) Fuel load accumulation sampling }\end{array}$ & $\begin{array}{l}\text { Kavanayen } \\
\text { Participatory project of cultural traditions and } \\
\text { practices linked to the use of fire } \\
\text { 1) Interviews } \\
\text { 2) Community workshops } \\
\text { 3) Video (1) } \\
\text { Participatory land use and food security project } \\
\text { 3) Interviews }\end{array}$ \\
\hline
\end{tabular}

Community meetings and workshops were used to adapt the process of reflexivity and enquiry to the deliberative, oral-based, decision-making structure of Pemon society (Thomas 1980). In total, six community workshops that were each 2-3 days long were organized throughout the year. Different participatory tools were used in these workshops, including oral testimonies, timelines, territory and community mapping, matrices, brainstorming, interviews, and group and plenary discussions (Davis 1992).

Topics discussed included the following:

Community history:

1. Who are we? The origin of the Pemon according to mythological beliefs.

2. Where do we come from? Historical and ancestral settlement areas.

3. Important historical figures, events, foundation processes of the village.

Current situation:

1. How has our community and territory changed over time? Discussion of social and environmental change (including fire use).
2. Things that we need to solve to improve our living conditions and environment.

3. Views of development.

A desired future:

1. Good and bad things of the past and of the present.

2. Vision of a desired future.

During the analysis of the current situation, it became clear that there were marked differences in the way Pemon youth and elders viewed environmental change and the role of fire in landscape formation. Thus, additionally, we agreed to carry out a process of community self-inquiry to understand and clarify these intergenerational discrepancies and tensions over the use of fire. In total, 29 in-depth interviews (14 young Pemon and 15 elders) about the knowledge and uses of fire were conducted. The interviews were processed and analyzed in situ and were presented at a community meeting, which proved very useful for clarifying differences in knowledge and cultural framings of fire among the Pemon. Further details about how the sample for this study was chosen, how the interviews were carried out, and the topics analyzed are provided in Rodriguez (2007). 


\section{Researching Pemon uses of fire}

Shortly after this research was conducted, a doctoral student from Cornell University, Bjørn Sletto, developed a participatory research of fire in the communities of Kumarakapay and Monte Bello - a smaller and more remote community where traditional burning is still practiced (Sletto 2006). Sletto's research sought to gain a deeper understanding of the changes in the use of fire in the area. He also based his research in the village of Kumarakapay. As part of the negotiations with Juvencio Gomez (who was still village chief) to carry out his research, Sletto offered to provide technical support for the Pemon territorial rights claim by helping produce a self-demarcated map of the eastern sector of the park (also known as Sector 5 according to the political division of the entire Pemon territory, which totals eight sectors). As stated before, life plans and territorial rights are conceived by the Pemon (and many indigenous peoples in Latin America) as two interlinked strategies in the pursuit of cultural revitalization and reassertion.

Thus, parallel to his research, Sletto led a 4-year participatory self-demarcation mapping project, which was conducted in the 12 communities in Sector 5. A group of 30 indigenous cartographers working with Sletto georeferenced areas used for agriculture, fishing, hunting, and gathering, as well as ancestral settlements and sacred places. Additionally, they conducted a series of community workshops, where groups of residents engaged in deliberations and map-making to document traditional geographic knowledge. A final map of Sector 5 was completed in 2005 and was distributed to all participating communities, as well as the National Cartography Office and conservation authorities (Sletto 2010).

This exhaustive process allowed Sletto to get a close insight into Pemon uses of fire and of the landscape. In addition to documenting cultural norms regarding the meaning and use of the landscape, Pemon youth and elders participated actively in documenting fire use and everyday practices through interviews and participant observation, and in developing and conducting surveys to assess the state of traditional knowledge about fire use among youth in both communities. Also, samples of fuel load accumulation were taken in separate locations in the vicinities of these communities to compare the frequency of fire practices in landscape formation (for details, see Sletto 2006, 2008).

\section{Researching risk factors}

In 2007, a new collaboration arose through a Venezuelan multidisciplinary, interinstitutional project entitled "Risk factors in reducing habitats in the Canaima National Park: vulnerability and tools for sustainable development" (Bilbao and Vessuri 2006). In addition to contributing to the understanding of risk factors in the Canaima National Park, a goal of this project was to facilitate dialogue about environmental risk and change with the Pemon (Sánchez-Rose and Vessuri 2009). The Life Plan was used as a platform for dialogue between the academic sector and the Pemon about the current and future social-ecological state of the Canaima National Park. Work was concentrated in Kumarakapay and Kavanayen. In the former, work resumed the process initiated in 1999, and focused on supporting the production of a community-authored book, and gathering the findings of the Pemon's Life Plan, with a focus on the history of Kumarakapay. The production of this book had been requested by the elders back in 1999 .
In Kavanayen, work adapted the process carried out in Kumarakapay in 1999 through a participatory evaluation of social-environmental changes and visions of the future. This was complemented with more detailed participatory studies on (a) historical reconstruction (Rodríguez 2016), (b) cultural traditions and practices linked to the use of fire (Millán 2015), and (c) land use and food security. Intercultural research teams were formed between researchers and community members to carry out research on these topics. This process lasted for a total of five years.

Since fire is considered to be one of the key risk factors in the Gran Sabana (Bilbao and Vessuri 2006), the project also initiated a paleoecological reconstruction of the landscape history (Leal 2010, Leal et al. 2016), an analysis of changes in the vegetation cover and land uses, and a study of fire behavior and its impacts in the Gran Sabana (Bilbao et al. 2009, 2010) ${ }^{[2]}$. Results of these studies were presented and discussed at various community assemblies that were part of the joint research activities, which prompted important discussions about the historical and social factors that have caused landscape change in the area.

\section{CONTRIBUTIONS}

Doing social-ecological research in collaboration with Pemon Life Plans has contributed to greater cognitive justice in Canaima National Park in various ways:

\section{Cultural revitalization and reassertion of indigenous rights}

First, the varied processes of self-reflection carried out in Kumarakapay and Kavanayen about their past, present, and future have made an important contribution to Pemon cultural revitalization and reassertion. One of the issues that the Pemon were more interested in and which received support in their Life Plan (particularly by the leaders and elders) was their historical reconstruction, both in terms of mythological and factual history. Important aspects of their past that were starting to be lost from the community's oral histories were discussed and made visible through these processes. Most significantly, in the case of Kumarakapay, there was a tangible outcome of this process: the publication of the community-authored book, The History of the Pemon of Kumarakapay (Roraimökok Damük 2010), which expresses the need to reconstruct the past and revalue the Pemon identity to be able to visualize a desired future. The publication of this book enabled the Pemon from Kumarakapay to regain a sense of identity and pride, which reinvigorated the community and its culture. Shortly after publishing their book, the inhabitants of Kumarakapay started undertaking a series of cultural activities, such as reconstructing the Pemon calendar, carrying out educational workshops in schools with the elders, creating fairs of the Pemon culinary culture, and holding native sports competitions.

The process of cultural reaffirmation experienced in Kumarakapay was also key for reasserting Pemon identity at a wider level, in particular, the need to advance the construction a Pemon Life Plan more widely. The Kumarakapay history book is now being used in schools and communities of Canaima National Park as a guide for developing their life plans. Other communities, such as Kavanayen, are also committed to producing their own history book. Additionally, shortly after the 
initial life plan discussion in Kumarakapay, a series of documents was produced in which the Pemon positioned their Life Plan process as a normative principle in their relationship with the State regarding the formulation of public policies (Gomez 2004, Pizarro 2006).

Collaboration with researchers was also important in terms of advancing the issues of indigenous rights in the park. The selfdemarcated map of the Pemon territory in Sector 5 that was produced in 2005 with support from Bjørn Sletto is now part of a formal claim for territorial property rights in the area (Sletto 2009).

\section{Revitalization of local knowledge of fire}

Another impact of the projects has been the revitalization of local environmental knowledge. The new research on fire that has been carried out over the last two decades has revealed important norms and principles that undergird Pemon's fire management system (Rodriguez 2004, 2007, Sletto 2010), many of which are not known or are ignored by state resource managers, and increasingly by young Pemon.

According to the Pemon worldview, fire helps them fulfill their ancestral obligation to care for the Gran Sabana. Any attempt to eliminate or restrict fire use is perceived as a threat to cultural identity and Pemon territoriality, and is likely to meet with resistance, particularly from elders and Pemon from villages that are subject to less cultural change. As in the case of other indigenous people, such as the aborigines of Kakadu National Park in Australia (Lewis 1989), Pemon use fire to "clean" the landscape and to make it look "beautiful." Also, like other indigenous peoples living in similar environments (Lewis 1989, Fairhead and Leach 1996, Mbow et al. 2000, Laris 2002, Moore et al. 2002, Mistry et al. 2005, McGregor et al. 2010, Miller and Davidson-Hunt 2010, Rodriguez et al. 2011), the Pemon use a prescribed burning system that involves setting grassland fires during certain times of the year in order to reduce fuel accumulation and thus prevent large, destructive forest fires. Thus, a reduction in the use of fire is perceived by the Pemon as a threat since it may lead to the accumulation of flammable biomass (Rodriguez 2007).

Yet, interviews and community discussions about fire also revealed that indigenous knowledge and perspectives of fire are not shared by all Pemon. Social change is leading to a decline in prescribed burning, which appears to result in critical accumulation of flammable biomass buildup in some areas of the Gran Sabana (Sletto 2006, 2008), and is contributing to differences in perceptions and knowledge of fire management between youth and elders (Rodriguez 2007, Sletto and Rodríguez 2013). Young Pemon from Kumarapapay, for instance, who have been subject to rapid social change and are more in contact with assimilation policies, are little aware of the important role of prescribed burning for preventing large destructive fires. A similar trend was also observed in Kavanayen during the life plan workshops, were young Pemon made no mention of the importance of fire in fire prevention but instead stressed its use as a productive tool. In contrast, in Monte Bello, a more traditional Pemon community, young Pemon revealed much greater knowledge of prescribed burning methods (Sletto and Rodriguez 2013).
Discussions in community meetings about the local use of fire and its changes prompted a re-evaluation of the ancestral lore that underpins this practice. Most significantly, the meetings led Pemon youth to reconsider their criticisms of the use of fire, and instead see the urgent need to learn from their grandparents about the use of fire in order to guarantee that they can continue to manage the landscape dynamically in the future (Rodriguez el al. 2013).

\section{Social validation of local knowledge of fire}

Additionally, ecological studies of fire started to give scientific validation to local Pemon knowledge and fire management practices. The fire behavior study, in particular, revealed important findings in relation to the role of fire in the Gran Sabana landscape. In this study, selective burns were carried out in 27 plots during the dry season over a period of seven years. The study revealed great variability in fire behavior in terms of fire, extent, temperature, and flame height. Furthermore, it showed that the variability in fire behavior, in turn, creates a mosaic of grassland patches with different fire histories, where the recently burned patches act as firebreaks in the propagation of fires that are started in neighboring patches. Based on this research, the authors concluded that the Pemon prescribed burning system reduces the occurrence of dangerous fires and furthers spatial and temporal vegetation heterogeneity (Bilbao et al. 2009, 2010). Most importantly, this study provided support for Pemon prescribed burning as an appropriate technique for biodiversity conservation and suggested that rather than eliminating Pemon fire management practices, the Pemon burning system is key in preventing potentially large destructive fires in critical conservation areas.

Likewise, the paleoecological reconstruction of the history of the Gran Sabana landscape revealed that in contrast to what has been commonly assumed, fire has been a permanent component of the Gran Sabana landscape for the last 7000 years (Leal 2010, Leal at al. 2016), similar to what has been reported in the Cerrado savannas in Brazil (Mistry et al. 2005). Because fires in the Gran Sabana have been shown to have primarily an anthropic origin, these findings suggest a long-term continuous human presence in the area and an active role of fire (and humans) in shaping and maintaining the landscape.

The discussion with the Pemon about the findings of the ecological and paleoecological studies have helped unveil other longer term historical factors that also seem to have played a role in shaping the contemporary Gran Sabana landscape. These have to do with the impact of colonial contact, in combination with drastic climate fluctuations that took place in the 19th century, which seemed to have played a role in catastrophic fires reported in the area in the beginning of the 20th century (Rodríguez et al. 2014). According to the testimony of elders from Kavanayen (Simon Perez, personal communication), colonial contact produced a drastic drop in savanna burns due to a combination of factors: the slave trade, interethnic wars, and migration, which in the long term contributed to overgrown and badly maintained savannas. These testimonies were later corroborated by historical sources that explain the immense impact that colonial contact had, which incentivized migrations and caused a reduction in the Pemon population in Gran Sabana in the 18th and 19th centuries (Rodríguez et al. 2014). 


\section{New meanings and social consensus of fire}

This combination of processes has started to create a social consensus about an alternative view and meaning of fire in Canaima National Park. A counter-narrative of fire has started to emerge, which emphasizes four important points:

1. Fire is an integral component of the Gran Sabana landscape.

2. The Pemon system of fire management could help reduce fires in high-risk areas.

3. Fire has to be considered as one of a variety of factors that could be contributing to vegetation change in the area. Socio-cultural changes coupled with fire suppression policies are leading to a decline in the Pemon prescriptive burning system, and as a result, to complex and poorly understood landscape changes.

4. Fire policies must change from a focus on suppression to an emphasis on management based on greater integration of different knowledge systems (traditional, social, scientific, and technical).

This counter-narrative of fire has been steadily finding its way into public discourse, through (a) academic publications (Bilbao et al. 2009, 2010, Leal 2010, Leal et al. 2016), (b) the organization of symposia and plenary discussions in congresses (García and Bilbao 2007), (c) discussions in local, national, and international training courses, and (d) popular publications via the national media, the international press, and the internet (Romero 2010, Morillo 2011, Barras 2015).

As a result, institutional discourses on fire have started to change. For instance, in some EDELCA departments, like Environmental Management, some policy documents suggest a turn in the conceptualization of fire policies, such as in the plan for integrated conservation of the Caroní Water Basin, drafted in 2007, which interestingly no longer mentions "fire control." Instead, the plan talks about fire management as a conservation tool for the integral management of the Caroni Water Basin (Sanchez et al. 2007). In this same plan, there is an explicit recognition of the importance of "privileging values, cultural and land use practices that are compatible with conservation," among them fire. Furthermore, the plan argues in favor of the need to "rescue and apply traditional uses of fire" as a part of a long-term conservation intervention. However, it cannot be said that these factors have led to profound changes in fire policies and therefore to structural changes in the fire conflict as such. Achieving this would require a more thorough revision of the existing fire management system than so far experienced and a new approach to fire, where Pemon and academic knowledge can work together in shaping and maintaining the landscape instead of working against each other.

What is clear, however, is that at present, there is much more recognition of the Pemon knowledge of fire management in Canaima National Park than there was two decades ago (Rodriguez 2004).

\section{CHALLENGES}

Despite their contributions, the processes described were not exempt from challenges and difficulties. In a context of strong cultural change as the one described, the building of a local wellbeing agenda cannot but be a contested process. Thus, dealing with fears, distrust, and community politics has also been an intrinsic part of the process developed to support the construction of a local well-being agenda, both in the self-demarcation project and in the life planning processes (Sletto 2009, Vessuri et al. 2014, Rodríguez 2016).

The life plan processes in particular had the challenge of being based on a relatively new concept, which despite its attractiveness to indigenous peoples, does not follow a clear or predefined model. Engagement of the projects with Pemon Life Plans was very much a learning-by-doing process. Although community leaders were aware of its use in other parts of Latin America, they were not clear on how to apply it in practice. This is precisely why they were interested in external collaboration. Yet, the down side of this was that at times this gave the impression that the Life Plan was driven by an outside agenda.

As a result, tensions were common among certain elders who claimed the Life Plan would weaken the Pemon selfdetermination agenda. In tune with their prior experiences with researchers, this group claimed that information generated through life plan meetings and workshops would only favor researchers' interests, and hence, were adamant about supporting the process.

On a different front, tension arose from community fractions who self-define themselves as more "modern" of "less indigenous." To them, the Life Plan process, rather than strengthening their sense of identity, was a threat to it, and thus were not interested in supporting it.

Both groups often openly confronted or sabotaged the processes by planting suspicion and distrust among community members, which demanded time and energy from researchers and the community life plan teams to dissipate doubts. Community assemblies were often the best place to air these issues and ensure local consent to continue the process, though sometimes informal conversations among the Life Plan project community members and their family networks were also effective in clarifying doubts.

Showing commitment to working through these tensions has been an important part of building and sustaining collaborative relations with the Pemon. Yet, the only thing that truly dissipated distrust toward the research projects was when outputs that are of most value and interest to the communities, such as the selfdemarcated map of Sector 5 or the publication of The History of the Pemon of Kumarakapay, were fruitfully taken to an end. This suggests that in order for cognitive justice to be made, it is very important for researchers to be truly committed to producing research outputs that are meaningful for communities, as much as they are to conventional academic products like scientific articles or books.

\section{CONCLUSIONS}

The following conclusions can be drawn from this case study to help think about cognitive justice, cultural revitalization, and local conceptualization of well-being as a supportive base for conservation practices:

1. In situations of prolonged epistemic violence and cultural change, the construction of local well-being agendas must go hand-in-hand with cultural revitalization. As this case study has shown, if cultural change is endangering indigenous peoples' 
connection with their land and their own survival, then cultural revitalization must be an intrinsic part of the way well-being is conceptualized in conservation. Reconnection with the past has been of particular importance in grounding a Pemon local wellbeing agenda in Canaima National Park.

2. Cultural revitalization can help create the conditions for a truthful dialogue about contentious issues linked to landscape change. Assisting in the development of life plans created a space in which the Pemon could feel secure to open up among themselves, and with others, about their social-ecological changes and current situation. This was decisive for them, and revealed fire management knowledge that challenges conventional explanations of landscape change that simplistically place the blame for such changes on the local use of fire.

3. Social-ecological research can play an important part in helping develop dialogues of knowledge. But as seen in Canaima National Park, this requires taking interculturality seriously. As said by Walsh (2005), building intercultural relationships "is not solely a matter of acknowledging, discovering or tolerating the other or cultural difference. It is neither about making identities static. It is about actively promoting processes of exchange that allow building spaces of encounter among different beings, knowledge, logics and practices." This requires an openness of mind on the part of researchers to critically consider the what, why, and what for of knowledge production in order to ensure its local relevance. This involves being willing to invest time, resources, and energy in helping revitalize indigenous knowledge, reconstruct collective memory, and promote the confrontation, exchange, and negotiation of Western knowledge with that of indigenous peoples in conditions of equity, even if at times this presupposes being drawn into messy community politics and tensions.

4. Supporting a local well-being agenda can help move toward a situation of greater cognitive justice in conservation. As a result of the work done in supporting the Pemon Life Plans, currently there are much more favorable conditions for negotiating new fire policies in the Canaima National Park than there were a decade ago. The power relations in the production of knowledge about fire have started to shift from a situation of exclusion of Pemon customary knowledge to one of wider recognition of both its cultural and environmental significance. New knowledge networks have started crafting a counter-narrative of fire that exposes the weak points in the dominant narrative and suggests ways forward for a more socially just and environmentally consistent approach to fire policies. Through these new knowledge networks, the Pemon have been able to start clarifying and articulating their views of fire so as to be in a stronger position to engage in dialogue with resource managers and scientists. Pemon knowledge of fire management, combined with results from studies of Pemon fire regimes, fire behavior ecology, and paleoecological research, now inform a counter narrative of landscape change that is influencing a shift in environmental discourse and policy-making toward an intercultural fire management approach.

5. The construction of life plans can play an important role in informing conservation policy-makers and intercultural fire management approaches. The progress made over the last two decades in Canaima National Park in changing the way academic and conservation circles perceive fire would not have been possible if social-ecological research had not started linking with the Pemon Life Plans. Apart from its contribution to local well-being agendas and to the construction of greater cognitive justice, such an approach can be of immense value to science and policymaking by helping open up new avenues for explorations about, and interpretations of, landscape use and change. In the case of Canaima National Park, engaging with Pemon Life Plans has helped give visibility to hidden local knowledge of fire, but also to considering the role that historical processes, which have been absent from the dominant narratives, has had in landscape change. The triangulation between local, paleoecological, archaeological, ecological knowledge, and historical records has given rise to more robust social-ecological knowledge that is locally relevant and can be of long-term use in conservation and fire management policies in the area.

Responses to this article can be read online at: http://www.ecologyandsociety.org/issues/responses. $\mathrm{php} / 9758$

\section{Acknowledgments:}

I am grateful to a variety of institutions and people who have supported the work I present in this paper. In Venezuela, the Venezuelan Science Council (CONICIT), now FONACIT, and the Venezuelan Institute for Scientific Research (IVIC) provided funding for fieldwork between 1997 and 2007. From abroad, the STEPS Centre from the University of Sussex, UK, through Grant RES-588-28-5001, provided support between 2011 and 2012 for systematizing and analyzing the 20 years of work carried out on cultural revitalization in CNP. More recently, the School of International Development from the University of East Anglia (UEA), through the Conservation, Justice and Markets Project (Grant ES/K005812/1) and the Transformations to Sustainability Programme, which is coordinated by the International Social Science Council and funded by the Swedish International Development Cooperation Agency (Sida), and implemented in partnership with the National Research Foundation of South Africa (Grant ISSC2015-TKN150317115354), provided support to write this manuscript. The Transformations to Sustainability Programme represents a contribution to Future Earth. On a more personal level, I wish to thank all my Pemon colleagues with whom I have worked since 1997, learning about their culture and the challenges they face in relating to the wider Venezuelan society. This includes Juvencio Gomez, Yraida Fernadez, Antonio González, Julio Enrique Lambos, Mario González, Yraida Fernandez, Yulita Gonzalez, Rafael Rodríguez, Filiberto Lambos, Cruz Perez, Nestor Perez, Domitila Sucre, Mariana Constati, Ana Karina Lambos, Humberto Chani, Francisco Perez, Irene Basabe, and Valeriano Constati and their families, as well as numerous other youth and elders in Kumarakapay and Kavanayen. Also to my work colleagues from academia, Bjorn Sletto, Isabelle Sanchez-Rose, Bibiana Bilbao, Alejandra Leal, Hebe Vessuri, Audrey Butt-Colson, Esteban Gutierrez, Erika Primiciero, and Rafael Gasson, with whom I have been able to learn over the years the huge challenges and potential of intercultural research in conservation. 


\section{LITERATURE CITED}

Appun, C. 1893. Roraima. Timehri 7:318-348.

Barras, C. 2015. Fires shape the Amazon savannah. New Scientist 227(3028):9. http://dx.doi.org/10.1016/S0262-4079(15)30677-1

Berkes, F. 2008. Sacred ecology. Second edition. Routledge, New York and London.

Bilbao, B., A. Leal, and C. Mendez. 2010. Indigenous use of fire and forest loss in Canaima National Park, Venezuela. Assessment of and tools for alternative strategies of fire management in Pemón indigenous lands. Human Ecology 38(5):663-673. http:// dx.doi.org/10.1007/s10745-010-9344-0

Bilbao, B., A. Leal, C. Méndez, and M. D. Delgado-Cartay. 2009. The role of fire in the vegetation dynamics of upland savannas of the Venezuelan Guayana. Pages 451-480 in M. A. Cochrane, editor. Tropical fire ecology: climate change, land use and ecosystem dynamics. Springer-Praxis, Heidelberg, Germany. http://dx.doi.org/10.1007/978-3-540-77381-8 16

Bilbao, B., and H. Vessuri. 2006. Proyecto Factores de riesgo en la reducción de hábitats en el Parque Nacional Canaima: vulnerabilidad y herramientas para el desarrollo sostenible. Proyecto de Grupo-FONACIT No. G-2005000514, USB-IVICUNEG- Estación Científica Parupa. Caracas, Venezuela.

Boddam-Whetham, J. W. 1879. Roraima and British Guiana, with a glance at Bermuda, the West Indies, and the Spanish Main. Hurst and Blackett, London, UK.

Brechin, S., R. Wilshusen, C. Fortwangles, and P. West, editors. 2003. Contested nature. Promoting international biodiversity with social justice in the twenty-first century. State University of New York Press, Albany, New York, USA.

Butt-Colson, A. 1985. Routes of knowledge: an aspect of regional integration in the circum-Roraima area of the Guiana Highlands. Antropológica 63/64:103-149.

Cash, D., W. Clark, F. Alcock, N. Dickson, N. Eckley, D. Guston, J. Jäger, and R. Mitchell. 2003. Knowledge systems for sustainable development. Proceedings of the National Academy of Sciences of the United States of America 100(14):8086-8091.

Christoffel, H. M. 1939. Informe definitivo sobre los suelos y posibilidades agrícolas en la Gran Sabana. In: S. E. Aguerrevere, V. M. Lopez, O. C. Delgado, and C. A. Freeman, editors. Exploracion de la Gran Sabana. Revista de Fomento. 3(19):596631.

Clementi, C. 1920. Through British Guiana to the summit of Roraima. T. Fisher Unwin, London, UK.

Davis, D. 1992. Herramientas para la Comunidad. Conceptos, Métodos y Herramientas para el Diagnóstico, Seguimiento y la Evaluación Participativos en el Desarrollo Forestal Comunitario. Manual de Campo 2. Roma: Organización de la Naciones Unidas para la Agricultura y la Alimentación (FAO).

Escobar, A. 2010 Epistemologías de la naturaleza y colonialidad de la naturaleza. Variedades de realismo y constructivismo. Revista Cultura y Naturaleza, Jardín Botánico de Bogotá José Celestino Mutis, pp. 49-71.

Fairhead, J., and M. Leach. 1996. Rethinking the forest-savanna mosaic. Colonial science and relicts in west Africa. Pages 105-
122 in M. Leach and R. Mearns, editors. The lie of the land. Challenging received wisdom about the African environment. International African Institute and James Currey Ltd., London, UK.

Galopin, G., and H. Vessuri. 2006. Science for sustainable development: articulating knowledges. Pages 35-52 in A. Guimaraes-Pereira, M. A. Cabo, and S. Funtowicz, editors. Interfaces between science and society. British Library, London, UK. http://dx.doi.org/10.9774/GLEAF.978-1-909493-67-4 4

Galtung, J. 1990. Cultural violence. Journal of Peace Research 27 (3):291-305. http://dx.doi.org/10.1177/0022343390027003005

García, J. 2009. Materiales para una Historia Pemon. Antropologica 52(111-112):225-240.

García, S., and B. Bilbao. 2007. Perspectivas institucionales, ecológicas y socioculturales de los incendios en el Parque Nacional Canaima. Pages 144-154 in J. C. Señaris and H. Rojas y D. Lew, editors. Actas del VII Congreso Venezolano de Ecología, La Sociedad es parte del Ecosistema. November 5-9, 2007. Ciudad Guayana, Venezuela Sociedad Venezolana de Ecología.

Ghimire, K., and M. Pimbert, editors. 1997. Social change and conservation. Environmental politics and impacts of national parks and protected areas. Earthscan Publications Limited.

Gómez, E. 1995. Programa control de incendios de vegetación, Cuenca Alta del Rio Caroní. Plan anual temporada 1995-1996. CVG-EDELCA, Puerto Ordaz, Venezuela.

Gómez, J. 2004. Aproximación Pemon para la Formulación de Políticas Públicas. Relatorías de las Asambleas Generales y Comunitarias. Ministry of Education and Sports, Federation of Indigenous of the State of Bolívar (FIEB), Econatura and The Nature Conservancy, Caracas, Venezuela.

Im Thurn, E. 1885 (1934). The ascent of Roraima. In R. R. Marett, editor. Thoughts, talks and tramps. Oxford University Press, London, UK.

International Council for Science (ICSU) 2005. Harnessing science, technology, and innovation for sustainable development. ICSU-ISTS-TWAS Consortium ad hoc Advisory Group.

Jansasoy, J. S., and A. L. Pérez. 2005. Plan de Vida. Propuesta para la supervivencia Cultural, Territorial y Ambiental de los Pueblos Indígenas. Fundación Zio-A'i, Unión de Sabiduría-The World Bank, Washington, D.C., USA.

Laris, P. 2002. Burning the seasonal mosaic: preventative burning strategies in the wooded savanna of southern Mali. Human Ecology 30(2):155-186. http://dx.doi.org/10.1023/A:1015685529180

Leach, M., and R. Mearns, editors. 1996. The lie of the land. Challenging received wisdom about the African environment. International African Institute and James Currey Ltd., London, UK.

Leal, A. 2010. Historia Holocena de la vegetación y el fuego en bordes sabanalbosque y turberas de la Gran Sabana, Guayana Venezolana. Dissertation. Universidad Simón Bolívar, Caracas, Venezuela.

Leal, A., B. Bilbao, J. C. Berrío, H. Behling, J. V. Montoya, and C. Méndez. 2016. Late-Holocene gallery forest retrogression in the Venezuelan Guayana: new data and implications for the 
conservation of a cultural landscape. The Holocene 26(7)10491063. http://dx.doi.org/10.1177/0959683616632892

Lewis, H. 1989. Ecological and technical knowledge of fire: aborigines versus park rangers in northern Australia. American Anthropologist 91(4):940-961.

Martin, A. 2017. Just conservation. Biodiversity, wellbeing and sustainability. Earthscan.

Mbow, C., T. Nielsen, and K. Rasmussen. 2000. Savanna fires in east-central Senegal: distribution patterns, resource management and perceptions. Human Ecology 28(4):561-583. http://dx.doi. org/10.1023/A:1026487730947

McGregor, S., V. Lawson, M. Christophersen, R. Kenneth, J. Boyden, P. Bayliss, A. Liedloff, B. McKaige, and A. Andersen. 2010. Indigenous wetland burning: conserving natural and cultural resources in Australia's World Heritage- listed Kakadu National Park. Human Ecology 38(6):721-729. http://dx.doi. org/10.1007/s10745-010-9362-y

Mignolo, W. D. 2008. Preamble: the historical foundation of modernity/coloniality and the emergence of decolonial thinking. Pages 12-52 in S. Castro-Klaren. A companion to Latin American literature and culture. Wiley-Blackwell. http://dx.doi. org/10.1002/9780470696446.cha

Millán, A. 2015. Bases para la creación de un plan de manejo integral del fuego en el Parque Nacional Canaima. Thesis. Universidad Simón Bolívar, Caracas, Venezuela.

Miller, A. M., and I. Davidson-Hunt. 2010. Fire, agency and scale in the creation of aboriginal cultural landscapes. Human Ecology 38:401-414. http://dx.doi.org/10.1007/s10745-010-9325-3

Mistry, J., A. Berardu, V. Andrade, T. Krahô, P. Krahô, and O. Leonardos. 2005. Indigenous fire management in the cerrado of Brasil: the case of the Krahô of Tocantís. Human Ecology 33 (3):365-386. http://dx.doi.org/10.1007/s10745-005-4143-8

Moore, P., D. Ganz, L. Cheng Tang, T. Enters, and P. Durst, editors. 2002. Communities in flames: proceedings of an international conference on community involvement in fire management. Food and Agriculture Organization of the United Nations and FireFight South East Asia, Bangkok, Thailand.

Morillo, M. 2011. Fuego Pemón in "Las crónicas de la Frontera". Blog of Morelia Morillo, Recuperado de: http://lascronicasdelafrontera. blogspot.com/2011/05/fuego-pemon.html

Ojha, H., J. Cameron and C. Kumar. 2009. Deliberation or symbolic violence? The governance of community forestry in Nepal. Forest Policy and Economics 11(5-6):365-374. http://dx. doi.org/10.1016/j.forpol.2008.11.003

Perez, C. 2009. "El Plan de Vida"-What is a life plan. Acción Colombia. Colombia Support Network, Spring 2009:3-4. http:// colombiasupport.net//wp-content/uploads/2012/02/

CSN_Spring_09_Newsletter1.pdf

Pérez, M., and A. Argueta. 2011. Saberes indígenas y diálogo intercultural. Cultura y representaciones Sociales 5(10):31-56.

Perry, K-K. Y., and J. Rappaport. 2013. Making a case for collaborative research with black and indigenous movements in Latin America. Pages 30-48 in C. Hale and L. Stephen, editors.
Otros saberes. Collaborative research on indigenous and Afrodescendents cultural politics. School for Advanced Research Press, New Mexico, USA.

Pilgrim, S., and J. Pretty, editors. 2013. Nature and culture. Rebuilding lost connections. Earthscan.

Pizarro, I. 2006. El plan de vida del pueblo Pemón, Pages 11-25 in J. Medina, V. Vladimir, editors. Conservación de la biodiversidad en los territorios indígenas Pemón de Venezuela: una construcción de futuro. The Nature Conservancy, Caracas, Venezeula.

Pregernig, M. 2006. Trandisciplinarity viewed from afar: sciencepolicy assessments as forums for the creation of transdisciplinary knowledge. Bioregional Insights 33(6):445-455.

Pretty, J., B. Adams, F. Berkes, S. Ferreira de Athayde, N. Dudley, E. Hunn, L. Maffi, K. Milton, D. Rapport, P. Robbins, E. Sterling, S. Stolton, A. Tsing, E. Vintinner, and S. Pilgrim. 2009. The intersections of biological diversity and cultural diversity: towards integration. Conservation and Society 7(2):1120-112.

Raymond, C. M., I. Fazey, M. S. Reed, L. C. Stringer, G. M. Robinson, and A. C. Evely. 2010. Integrating local and scientific knowledge for environmental management. Journal of Environmental Management 91(8):1766-1777. http://dx.doi. org/10.1016/j.jenvman.2010.03.023

Rodríguez, I. 2004. Conocimiento indígena vs. científico: el conflicto por el uso del fuego en el Parque Nacional Canaima, Venezuela. Interciencia 29(3):121-129.

Rodríguez, I. 2007. Pemon perspectives of fire management in Canaima National Park, southeastern Venezuela. Human Ecology 35(3):331-343. http://dx.doi.org/10.1007/s10745-006-9064-7

Rodríguez, I. 2014. Canaima National Park and World Heritage Site: spirit of evil? In S. Disko and H. Tungendhat, editors. World heritage sites and indigenous peoples' rights. IWGIA, Forest Peoples Programme and Gundjeihmi Aboriginal Corporation, Copenhagen, Denmark.

Rodríguez, I. 2016. Historical reconstruction and cultural identity building as a local pathway to 'living well' amongst the Pemon of Venezuela. Pages 260-280 in S. White and C. Blackmore, editors. Cultures of wellbeing. Method, place and policy. Palgrave MacMillan, Hampshire, UK. http://dx.doi.org/10.1057/978113$\underline{753645711}$

Rodríguez, I., P. Albert, C. La Rose, and C. Sharpe. 2011. A study of the use of fire by Amerindian communities in South Rupununi, Guyana, with recommendations for sustainable land management. Forest Peoples Project, Moreton-in-Marsh, UK.

Rodríguez, I., S. Bjørn, B. Bilbao, I. Sanchez-Rose, and A. Leal. 2013. Speaking of fire: reflexive governance in landscapes of social change and shifting local identities. Journal of Environmental Policy Making \& Planning. http://dx.doi. org/10.1080/1523908X.2013.766579

Rodríguez, I., R. Gasson, A. But-Colson, A. Leal, and B. Bilbao. 2014. Ecología Histórica de la Gran Sabana (Estado Bolívar, Venezuela) entre los siglos XVIII y XX. In R. Stephen, editor. Antes de Orellana. Actas del III Encuentro Internacional de Arqueología Amazónica. Instituto Francés de Estudios Andinos, Facultad Latinoamericana de Ciencias Sociales, Embajada de EEUU, Quito, Ecuador. 
Romero, S. 2010. In Venezuela's savanna, clash of science and fire. New York Times, April 23, 2010.

Roroimökok-Damük. 2010. La Historia de los Pemon de Kumarakapay. In I. Rodríguez, J. Gómez, and Y. Fernández, editors. Instituto Venezolano de Investigaciones Científicas, Fundación Futuro Latinoamericano, Inwent y Forest Peoples Programme. Ediciones IVIC. Caracas, Venezuela.

Sanchez, R., S. Garcia, and D. De Armas. 2007. Rol del fuego en el del Río Caroní. Ponencia Presentada en el en el Simposio "Perspectivas Institucionales, Ecológicas y Socio-culturales para el manejo del fuego en el Parque modelo de conservación para una corporación de energía eléctrica en la Cuenca Nacional Canaima”, VII Congreso Venezolano de Ecología. La sociedad es parte del ecosistema. Hotel Intercontinental, Puerto Ordaz, 09 de Noviembre 2007.

Sánchez-Rose, I., and H. Vessuri. 2009. Riesgo, ambiente y gobernabilidad. Aprendizajes de una investigación interdisciplinaria. Pensamiento Iberoamericano (5):149-170.

Santos, B. S., editor. 2007. Cognitive justice in a global world: prudent knowledges for a decent life. Lexington Books, Lanham.

Schomburgk, R. H. 1840. Journey from Fort Joaquin, on the Rio Branco, to Roraima, and thence by the rivers Parima and Merewari to Esmeralda, on the Orinoco, in 1838-9. Journal of the Royal Geographical Society of London 10:191-247. http://dx. doi.org/10.2307/1797841

Sletto, B. 2006. Burn marks: the becoming and unbecoming of an indigenous landscape. Dissertation. Cornell University, Ithaca, New York, USA.

Sletto, B. 2008. The knowledge that counts: institutional identities, policy science, and the conflict over fire management in the Gran Sabana, Venezuela. World Development 36:19381955. http://dx.doi.org/10.1016/j.worlddev.2008.02.008

Sletto, B. 2009. 'Indigenous people don't have boundaries': reborderings, fire management, and productions of authenticities in indigenous landscapes. Cultural Geographies 16(2):253-277. http://dx.doi.org/10.1177/1474474008101519

Sletto, B. 2010. Autogestión en representaciones espaciales indígenas y el rol de la capacitación y concientización: el caso del Proyecto Etnocartográfico Inna Kowantok, Sector 5 Pemón (Kavanayén-Mapauri), La Gran Sabana. Antropológica 11(3):4375.

Sletto, B., and I. Rodriguez. 2013. Burning, fire prevention and meanings of landscape among the Pemon, Gran Sabana, Venezuela: toward an intercultural approach to wildland fire management in neotropical savannas. Journal of Environmental Management 115(30):155-166. http://dx.doi.org/10.1016/j. jenvman.2012.10.041

Smith, L. T. 2012. Decolonizing methodologies: research and indigenous peoples. Zed Books.

Tate, G. H. H. 1930. Notes on the Mount Roraima Region. Geographical Review 20(1):53-68. http://dx.doi.org/10.2307/209126
Thomas, D. J. 1980. Los Pemon in Lizarralde. In R. and H. Seijas, editors. Los aborigenes de Venezuela. Etnologia Contemporanea. Fundación La Salle de Ciencias Naturales, Caracas, Venezeula.

Vessuri, H., I. Sánchez-Rose, I. Hernández. L. Hernández, L. Bravo, and I. Rodríguez. 2014. "Desigualdades de conocimiento y estrategias para reducir las asimetrías. El trabajo de campo compartido y la negociación transdisciplinaria”. Working Paper Series 62. International Research Network on Interdependent Inequalities in Latin America, Berlin, Germany.

Visvanathan, S. 1997. A carnival for science: essays on science, technology and development. Oxford University Press, London, UK.

Walsh, C. 2005. Interculturalidad, conocimientos y decolonialidad. Signo y Pensamientos 24(46):39-50.

World Bank. 2006. Project brief on a proposed grant from the Global Environment Facility Trust Fund in the amount of USD 6 million to the government of Venezuela for a Venezuela-expanding partnerships for the National Parks System Project.

[1] The name of the park was inspired by the novel "Canaima" by Venezuelan author Rómulo Gallegos. The novel, written in 1935, is set in ancestral Pemon lands (north of Canaima National Park), and represents a strong complaint against abusive leadership and the domination and control of humans over nature, characteristic of that time.

${ }^{[2]}$ This long-term fire experiment was initiated in 1999 under the "Atmosphere-biosphere interaction in Gran Sabana, Canaima National Park" multidisciplinary project and continued within the Risk Project. 